\title{
KE MAMPUAN STRATEGIS PESAWAT UDARA NIR AWAK BPPT UNTUK DIOPERASIKAN DARI KAPAL PERANG
}

\section{THE STRATEGIC FLIGHT PERFORMANCE OF BPPT UAV FOR SUPPORTING THE NAVAL OPERATION}

\section{Perhitungan J angkauan, Ketahanan dan Batas Ketinggian Terbang serta Paparan Kelayakan Operasional Flying Wing pada Kapal Perang Indonesia}

\author{
J emie Muliadi a, Dewi H. Budiarti a, Akhmad Rifai a, Dyah J atiningrum ' \\ a Pusat Teknologi Industri Pertahanan dan Keamanan (PTIPK - BPPT), \\ Lt.2 Gd. 256 Manajemen-Hankam, Puspiptek, Serpong 15314. \\ b Pusat Teknologi Industri dan Sistem Transportasi (PTIST - BPPT), \\ Lt.3 Gd. Tekno 2, Puspiptek, Serpong 15314. \\ e-mail : jemie.muliadi@bppt.go.id, dewi.habsari@bppt.go.id , akhmad.rifai@bppt.go.id, \\ dyah.jatiningrum@bppt.go.id
}

\begin{abstract}
Abstrak
Salah satu cara pemenuhan Minimum Essential Force TNI-AL adalah melalui peningkatan kemampuan Alutsista yang sudah dimiliki. Peningkatan kemampuan tersebut dapat dilakukan dengan melengkapi kapal perang (KRI) dengan PUNA BPPT. Penempatan PUNA BPPT pada kapal perang TNI-AL akan mendukung fungsi operasionalnya, antara lain patroli perbatasan, pengawasan wilayah bahkan hingga pengintaian.

Dalam naskah ini akan disajikan kemampuan jangkauan jarak, ketahanan dan ketinggian terbang PUNA BPPT yang relevan dengan pengoperasiannya dari kapal perang. Perhitungan parameter prestasi terbang PUNA BPPT akan dilakukan dengan pengolahan data uji terbang, dokumen perancangan, dan pendekatan-pendekatan perhitungan yang terkait.

Meskipun PUNA belum mampu menggantikan keseluruhan fungsi helikopter di kapal perang, tapi beberapa fungsi penting tersebut dapat dikerjakan oleh PUNA. PUNA beroperasi dengan konsumsi bahan bakar yang sangat sedikit dan dapat bertolak dan mendarat dengan lebih mudah. Dengan sifat Nir Awak-nya, penggunaan PUNA mengurangi resiko terhadap keselamatan personel yang mengoperasikannya. Hal-hal ini menjadi acuan BPPT dalam mengembangkan PUNA yang dapat beroperasi dari kapal perang.
\end{abstract}

Kata kunci : PUNA KRI, PUNA BPPT, PUNA tanpa ekor, Jangkauan Terbang, Ketahanan Terbang

\begin{abstract}
One of the method to achieve the Minimum Essential Force for the Indonesian Navy is the improvement of the current capability of the existing weapons and defense apparatus. Equipping the warship with reliable UAVs will support their main mission such as border patrol, surveillance, and reconnaissance.

In this work, the BPPT UAV range, endurance, and ceiling will be presented to emphasis its ability for operation from the warship. By processing its flight test data, together with design documents and using proper approximation method, the flight performance parameters will be derived, and its values will be calculated.

The UAV can not totally replace the role of navy's helicopter of the warship, but partially, the UAV offers better features such as lower fuel consumption, and the easiness in take off and landing process. The personnel involved in the UAV mission can operate it safely compared to the manned helicopter. These motives
\end{abstract}


encourange BPPT to develop a UAV that is portable enough to be operated from frigate class warships.

Key words : Naval purpose UAV, BPPT UAV, Flying Wing, Flight Range, Flight Endurance

Diterima (received) : 14 Juni 2017, Direvisi (reviewed) : 9 Juli 2017, Disetujui (accepted) : 30 Juli 2017

\section{PENDAHULUAN}

\section{Perbatasan Wilayah Negara Kesatuan Republik Indonesia}

Sebagian besar perbatasan Indonesia terdiri dari perbatasan laut. Hal ini adalah konsekuensi dari kondisi geografis Indonesia yang unik, yaitu negara kepulauan yang terbentang di wilayah yang cukup luas. Pengawasan garis perbatasan yang sangat panjang ini menjadi salah satu tugas TNI AL. Tugas ini bisa jadi adalah pekerjaan yang sangat berat, terutama karena kondisi sarana dan prasarana TNI yang ada sekarang.

Saat ini, garis pantai Indonesia terbentang sepanjang 97 ribu $\mathrm{km}^{1}$. Dengan panjang garis pantai yang mencapai puluhan ribu kilometer dan garis perbatasan darat hingga ribuan kilometer, maka masih terdapat persoalan perbatasan yang belum selesai. Dalam Buku Putih Pertahanan Indonesia ${ }^{2)}$, dijelaskan isu tentang pulaupulau kecil terluar/terdepan yang sebenarnya berperan sangat menentukan dalam penentuan batas wilayah Indonesia. Pulaupulau tersebut berfungsi sebagai titik pangkal penarikan batas wilayah NKRI. Namun terjadi masalah dalam eksistensi, status kepemilikan, konversi lingkungan, pengamanan dan pengawasannya. $\mathrm{Di}$ sisi lain kondisi pulau-pulau kecil terluar semakin kritis karena banyak yang tidak berpenghuni dan kondisi alamnya tidak layak untuk dihuni, antara lain tidak terdapat cukup kandungan daya air tawar dan ruang hidup yang tidak cukup.

Dalam bidang pengamanan, pulau-pulau kecil terluar berpotensi diperjualbelikan atau disewakan secara tidak sah kepada pihak atau warga negara asing. Dari beberapa kasus, ditemukan beberapa pulau kecil yang dikelola oleh perorangan, bahkan ada yang dikelola oleh pihak asing. Praktek-praktek tersebut menjadi ancaman yang dapat menyulitkan pemerintah dan bangsa Indonesia. $\mathrm{Di}$ sisi lain, keterbatasan pembangunan pada pulau-pulau di daerah perbatasan menjadi ancaman stabilitas politik, hukum dan keamanann22). Dari paparan ini, dapat terlihat pentingnya kehadiran sarana pengawasan dengan kemampuan di atas kesanggupan fisik manusia.

Dalam Buku Putih tersebut ${ }^{2)}$, diidentifikasi pula beberapa jenis gangguan di wilayah perbatasan, meliputi, pencurian ikan, penyelundupan dan perompakan. Selain itu, terdapat pula ancaman nirmiliter yang bersifat lintas Negara, yaitu ancaman keamanan lintas negara yang terorganisir yang melibatkan pelaku-pelaku dari negara lain. Bentuk ancaman dimaksud antara lain aksi terorisme internasional, gangguan keamanan di wilayah laut, gangguan keamanan dirgantara, dan gangguan keamanan di sepanjang garis perbatasan darat. Bentuknya berupa penyelundupan manusia, senjata dan bahan peledak, serta perompakan dan pembajakan, pembalakan liar, penangkapan ikan secara tidak sah, dan lain-lain.

\section{Peningkatan Minimum Essential Force TNI-AL}

Minimum Essential Force (MEF) adalah kekuatan minimal pokok yang diperlukan oleh TNI untuk dapat menjaga kedaulatan Negara Kesatuan Republik Indonesia secara optimum. Untuk memenuhi MEF ini maka sarana dan prasarana TNI perlu ditingkatkan. Salah satunya adalah dengan meningkatkan kemampuan sarana TNI-AL yang telah ada. Peningkatan kemampuan kapal patroli perbatasan kelas fregat dapat diwujudkan melalui pengoperasian Pesawat Udara Nir Awak (PUNA). PUNA dapat digunakan untuk melakukan pengawasan terhadap pulaupulau terpencil di perbatasan. Penerapan hal ini akan meningkatkan luasan area pengawasan, sehingga dapat mencegah 'hilangnya' pulau-pulau tersebut ke negara tetangga.

\section{Pesawat Udara Nir Awak Badan Pengkajian dan Penerapan Teknologi (PUNA BPPT)}

Konfigurasi PUNA yang dikembangkan oleh BPPT untuk operasi dari atas kapal kelas fregat adalah pesawat udara nir awak dengan konfigurasi flying wing. Pesawat ini dapat lepas landas dengan menggunakan launcher (pelontar) dan mendarat dengan menggunakan landing net (jaring pendarat). 
Kemampuan Srategis Pesawat Udara NIR Awak BPPT untuk Dioperasikan dari Kapal Perang. (Jemie Muliadi, Dewi H. B., Akhmad Rifai, Dyah Jatiningrum)

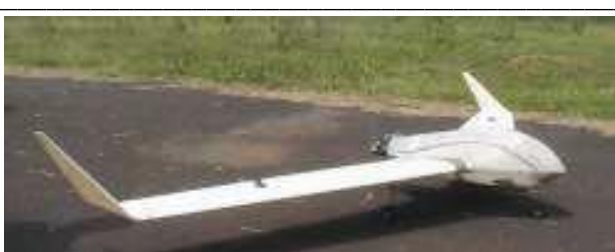

Gambar 1.

PUNA BPPT jenis Flying Wing

Dari kapal perang TNI-AL, PUNA dirancang untuk melaksanakan misi pengawasan pulau-pulau terluar Indonesia dengan real-time video baik dengan kamera konvensional maupun inframerah. Hal ini adalah salah satu aplikasi PUNA yang dapat dioperasikan pada kapal perang, di samping banyak kegunaan lain yang masih bisa dieksplorasi ${ }^{16)}$.

\section{Kapal Perang TNI-AL Kelas Fregat}

Sebagai salah satu kekuatan armada TNI $A L$, kapal perang dilengkapi dengan berbagai peralatan pendukung operasi misinya. Salah satu peralatan yang sangat sensitif adalah antena radar yang berada di geladak bagian tengah kapal ${ }^{17)}$. Berbagai peralatan operasional tersebut secara langsung maupun tidak langsung akan menjadi faktor yang menentukan prosedur penggunaan PUNA di atas kapal perang baik dari segi lokasi maupun prosedur takeoff dan landing yang akan diterapkan.

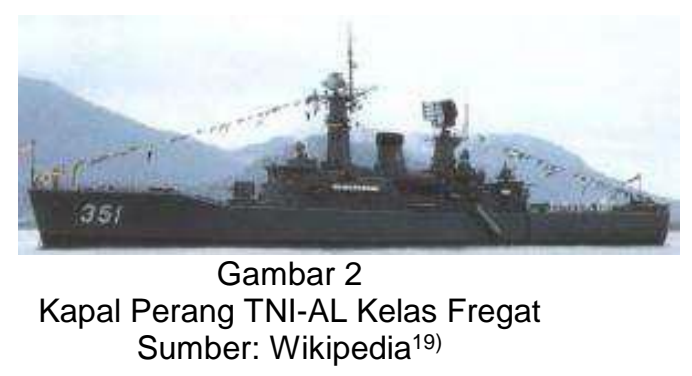

Pada dek bagian belakang kapal perang kelas fregat terdapat helipad yang mampu memfasilitasi operasi light helicopter seperti jenis NBO 105 Bolkow. Panjang helipad ini adalah 24,6 meter, sedangkan lebarnya adalah 12 meter. Dari segi dimensi dan lokasi, area helipad ini dapat digunakan dalam pengoperasian PUNA.

Konsepsi take-off dan landing di atas kapal, bukanlah hal baru. Banyak pesawat berkemampuan Short Take-Off and Landing (STOL) dan Vertical Take-Off and Landing (VTOL) juga mampu lepas landas dan mendarat di atas kapal laut ${ }^{21)}$. Gambar 3 memperlihatkan lokasi pendaratan di atas $\mathrm{KRI}$.

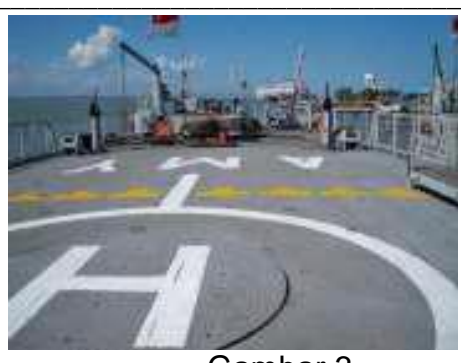

Gambar 3

Helipad Lokasi Peluncuran dan Pendaratan PUNA di Kapal Perang

\section{TAKE-OFF LANDING PUNA BPPT DI ATAS KAPAL PERANG}

\section{Peluncuran PUNA dari Kapal Perang}

Seperti halnya operasi di darat, peluncuran PUNA dari atas kapal perang, akan menggunakan launcher yang sama dengan panjang 4,77 meter. Launcher yang digunakan PUNA BPPT ini dapat dipasang di atas helipad yang berukuran 24,6 meter x 12 meter. Launcher dapat dipasang sejajar panjang ataupun lebar helipad. Arah angin dan kecepatan kapal perlu diperhatikan untuk performa takeoff yang optimal. Selain itu, pesawat harus diluncurkan menjauh dari badan kapal agar tidak membahayakan peralatan maupun personel. Terdapat tiga kemungkinan peluncuran yaitu arah belakang, kanan atau kiri kapal, yang dapat diatur dengan mudah karena launcher yang digunakan cukup portabel. Gambar 4 memperlihatkan pelontar yang digunakan.

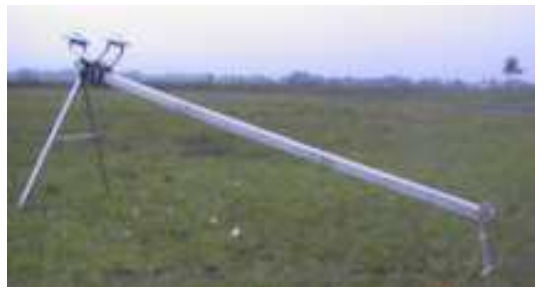

Gambar 4

Launcher PUNA BPPT

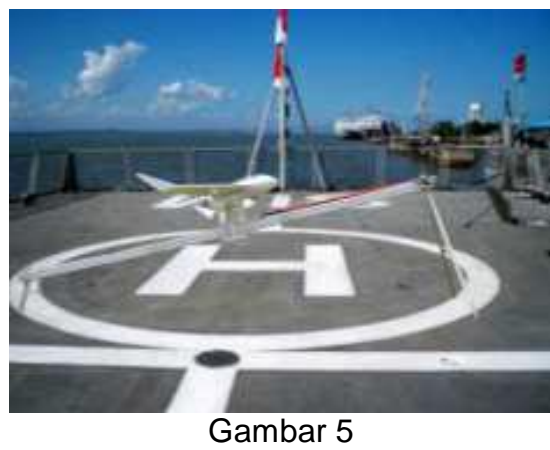

Ilustrasi Persiapan Peluncuran PUNA BPPT dari Helipad Kapal Perang 


\section{Pendaratan PUNA}

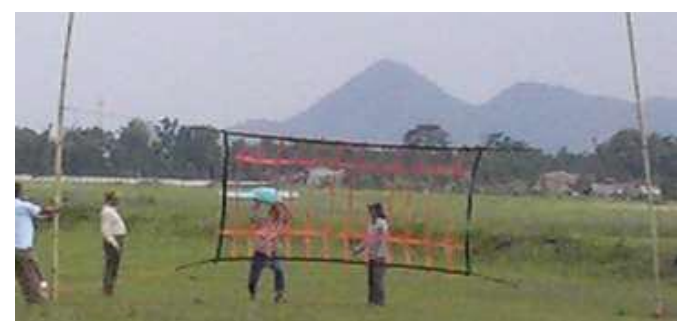

Gambar 6

Jaring Pendarat PUNA BPPT

Pesawat PUNA BPPT ini memiliki bentang sayap sepanjang 2,988 meter. Untuk mendarat, PUNA menggunakan jaring yang berukuran 8 meter $\times 5$ meter dengan tinggi tiang 6 meter. Lebar area yang dibutuhkan untuk mendarat adalah minimal 10 meter. Oleh karena itu, jaring ini dapat dipasang di atas helipad kapal perang (baik melintang maupun memanjang). Gambar 6 memperlihatkan jaring pendarat yang digunakan.

Pemasangan jaring pendarat (landing net) dapat dilakukan dengan mengikatkan tali jaring pada lubang-lubang khusus di geladak kapal perang.

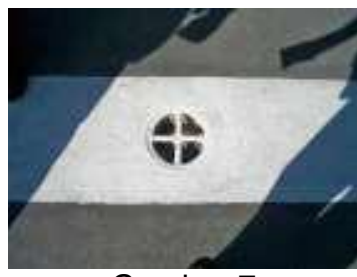

Gambar 7

Lubang Penambatan di Geladak Kapal Perang

Beberapa hal yang perlu diperhatikan dalam landing adalah sebagai berikut:

- Arah landing dan penempatan jaring. Berbagai peralatan operasional di bagian tengah geladak kapal mempengaruhi implementasi operasi PUNA. Ketika takeoff, arah terbang pesawat dapat diarahkan dengan relatif mudah, namun pada saat landing hal ini akan menjadi lebih sulit. Dimensi pesawat yang cukup kecil menyebabkan sensitifitas reaksi terhadap kecepatan angin, sehingga pilot harus ekstra hati-hati dalam menjaga lintasan approach menuju titik pendaratan. Untuk meminimalkan resiko, approach dilakukan dari sisi kanan atau kiri kapal sehingga lintasan terbang tidak mengarah ke tengah geladak.

- Terdapat dua kemungkinan penempatan jaring, yaitu pada sisi luar atau bagian tengah geladak belakang.
Apabila jaring ditempatkan pada bagian sisi luar, maka harus disiapkan pula jaring penadah horizontal di bagian bawah agar pesawat tidak jatuh ke laut. Apabila jaring ditempatkan di bagian tengah geladak belakang, perlu disiapkan alas agar badan pesawat tidak rusak ketika terpental dari jaring ke lantai geladak.

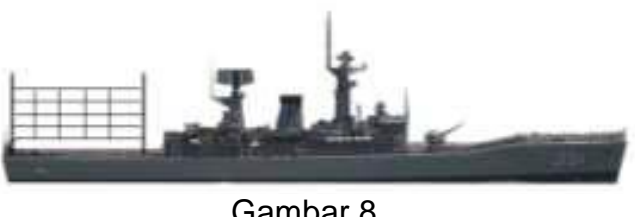

llustrasi Pemasangan Jaring Pendarat di Kapal Perang

- Arah dan kecepatan kapal. Agar proses pendaratan PUNA berjalan dengan lancar, sebaiknya kapal berada dalam posisi diam (turun jangkar) sehingga lintasan approach dapat dijaga tetap. Kemungkinan lain adalah kapal diam tanpa dijangkar, tetapi sebaiknya dilakukan simulasi terlebih dahulu agar pilot dan juru mudi dapat mensinkronkan tahapan operasional yang diperlukan.

- Pengamanan peralatan kapal dan personil. Meskipun arah lintasan approach dan penempatan jaring telah ditentukan sedemikian rupa untuk menghindari bahaya terhadap peralatan operasional dan personil kapal, satu langkah tambahan perlu dilakukan. Sebuah jaring tambahan dapat dipasang diantara peralatan kapal dan area operasi PUNA. Selain itu, hanya personil yang berkaitan langsung dengan operasi PUNA yang boleh berada di area terkait, dengan memperhatikan batasan yang telah ditentukan. Semua personil lainnya harus berada di belakang garis jaring pengaman.

\section{J ANGKAUAN TERBANG PUNA BPPT}

\section{Persamaan Jangkauan Terbang \\ Maksimum \\ Jangkauan Terbang (Range) adalah} jarak yang ditempuh oleh pesawat udara dengan sejumlah bahan bakar yang dibawa dan sehimpunan parameter terbang tertentu ${ }^{3)}$.

Asselin ${ }^{3)}$, merumuskan persamaan Jangkauan Terbang Pesawat Udara dalam ekspresi berikut: 
Kemampuan Srategis Pesawat Udara NIR Awak BPPT untuk Dioperasikan dari Kapal Perang. (Jemie Muliadi, Dewi H. B., Akhmad Rifai, Dyah Jatiningrum)

$$
X_{\mathrm{BR}}=\frac{\eta_{P} E_{m}}{S F C_{P}} \ln \left(\frac{1}{1-\varsigma}\right)
$$

et al.5). Untuk 1,5 liter bahan bakar, maka dengan persamaan (2) akan diperoleh nilai $\zeta$ sebesar 0,1033 .

Dengan notasi:

$$
\begin{aligned}
& X_{\mathrm{BR}} \quad \text { : Jangkauan Terbang } \\
& S F C_{P} \text { : Konsumsi Bahan Bakar Tiap } \\
& \text { Satuan Waktu (Piston-Prop } \\
& \text { Engine Specific Fuel } \\
& \text { Consumption) } \\
& \eta_{P} \quad: \text { Faktor Efisiensi Baling-Baling } \\
& E_{m} \quad \text { : Nilai Maksimum Efisiensi } \\
& \text { Aerodinamika (Perbandingan } C_{L}
\end{aligned}
$$

\begin{tabular}{|c|c|c|c|}
\hline Parameter & Nilai & Satuan & Sumber \\
\hline MTOW & 10,5 & $\mathrm{Kg}$ & $\begin{array}{l}\text { Budiarti et } \\
\text { al. }{ }^{4)} \text { pp.8 }\end{array}$ \\
\hline $\begin{array}{l}\text { Fuel Volume } \\
\text { Rate }\end{array}$ & 1 & Liter/jam & $\begin{array}{l}\text { Budiarti et } \\
\text { al.5) pp. } 12\end{array}$ \\
\hline $\begin{array}{l}\text { Fuel Tank } \\
\text { Capacity }\end{array}$ & 1500 & $\mathrm{Cc}$ & $\begin{array}{l}\text { Budiarti et } \\
\text { al. }{ }^{4} \text { pp.8 }\end{array}$ \\
\hline $\begin{array}{l}\text { Propeller } \\
\text { Diameter }\end{array}$ & 14 & Inch & $\begin{array}{l}\text { Budiarti et } \\
\text { al. }{ }^{4} \text { pp.8 }\end{array}$ \\
\hline $\begin{array}{l}\text { Propeller } \\
\text { Pitch }\end{array}$ & 6 & Inch & $\begin{array}{l}\text { Budiarti et } \\
\text { al. }{ }^{4} \text { pp. } 8\end{array}$ \\
\hline $\begin{array}{l}\rho_{\text {Fuel }}, \text { Fuel } \\
\text { Density }\end{array}$ & 0,723 & $\mathrm{~g} / \mathrm{cm}^{3}$ & $\begin{array}{l}\text { Sururi \& } \\
\text { Waluyo6) }\end{array}$ \\
\hline
\end{tabular}

Nilai-nilai dari parameter $S F C_{P}, E_{m}, \eta_{P}$, dan $\zeta$ akan dihitung dengan pengolahan $\mathrm{R}$ aw Data dari Mission Report Uji Terbang PUNA dan Analisa Teknis PUNA. Raw Data tersebut ditabelkan sebagai berikut:

Tabel 1.

Raw Data Perhitungan Jangkauan Terbang Maksimum PUNA di Atas Kapal Perang

Sedangkan perhitungan parameterparameter $\zeta, E_{m}, S F C_{P}$, dan $\eta_{P}$, akan disajikan pada tahapan-tahapan berikut:

\section{Rasio B erat Bahan Bakar (Fuel Ratio, \)}

Rasio Berat Bahan Bakar Pesawat menyatakan perbandingan antara berat bahan bakar, $W_{\text {Fuel }}$ yang dibawa dengan berat lepas landasnya. Parameter $\zeta$ ini dinyatakan secara matematis dalam persamaan ${ }^{3)}$ :

$$
\varsigma=\frac{W_{\text {Fuel }}}{M T O W \cdot g}=\frac{\text { Vol }_{\text {Fuel }} \cdot \rho_{\text {Fuel }} \cdot g}{M T O W \cdot g}
$$

Untuk maksimalisasi jangkauan terbang, maka akan digunakan berat lepas landas sebesar Maximum Take-Off Weight, MTOW dan Volume Tangki Bahan Bakar dari Budiarti

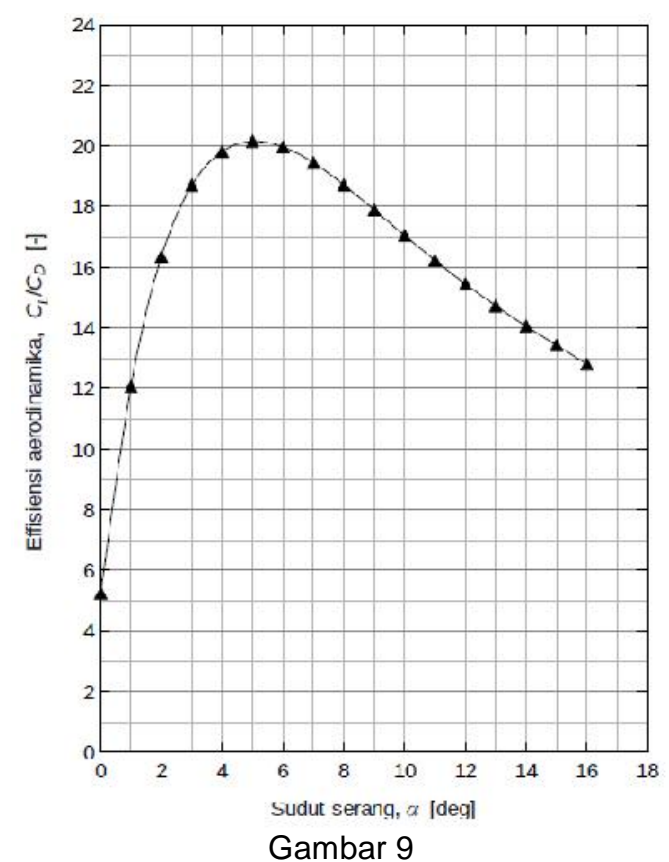

Distribusi Efisiensi Aerodinamika terhadap Sudut Serang (Sumber: Hasim \& Madhapi ${ }^{7}$ )

Efisiensi Aerodinamika Maksimum $\left(E_{m}\right)$, serta $C_{L}$ dan $C_{D}$ pada Kondisi Tersebut

Nilai Efisiensi Aerodinamika, $E$ adalah properti aerodinamika yang menyatakan perbandingan gaya angkat PUNA terhadap gaya hambatnya (Lift to Drag Ratio). Secara matematis, nilai $E$ dihitung dengan persamaan $^{3)}$ :

$$
E=L / D
$$

Maka parameter $E$, juga menghubungkan koefisien gaya angkat pesawat, $C_{L}$, dan koefisien gaya hambatnya, $C_{D}$. Definisi $C_{L}$ dan $C_{D}$ dinyatakan dengan hubungan berikut ini3) :

$$
\begin{aligned}
& L=\frac{1}{2} \rho V^{2} S C_{L} \\
& D=\frac{1}{2} \rho V^{2} S C_{D}
\end{aligned}
$$

Dengan:

$$
\begin{array}{ll}
\rho & : \text { Massa Jenis Udara } \\
V & : \text { Kecepatan Terbang } \\
S & : \text { Luas Sayap }
\end{array}
$$


Maka, substitusi (4) dan (5) ke (3), akan menghasilkan:

$$
E=\frac{C_{L}}{C_{D}}
$$

Hasim dan Madhapi dalam) menghitung nilai koefisien gaya angkat dan koefisien gaya hambat PUNA BPPT, serta Efisiensi Aerodinamika, E. Nilai Efisiensi Aerodinamika, E, disajikan dengan kurva pada Gambar 9 sebagai fungsi dari sudut serang, $\alpha$.

Dari kurva Distribusi Efisiensi Aerodinamika PUNA BPPT pada Gambar 9, terlihat bahwa Efisiensi Aerodinamika mencapai nilai maksimum bila PUNA diterbangkan pada Sudut Serang, $\alpha$, sebesar 5०. Nilai Efisiensi Aerodinamika maksimum, $\mathrm{E}_{\mathrm{m}}$, Koefisien Gaya Angkat, $C_{L}$, dan Koefisien Gaya Hambat, $C_{D}$, pada kondisi tersebut, disajikan pada Tabel 2.

Tabel 2.

Efisiensi Aerodinamika Maksimum, serta Koefisien Gaya Angkat dan Koefisien Gaya Hambatnya

\begin{tabular}{llcl}
\hline Parameter & Notasi & Nilai & Sumber \\
\hline $\begin{array}{l}\text { Efisiensi } \\
\begin{array}{l}\text { Aerodinamika } \\
\text { maksimum }\end{array}\end{array}$ & $\mathrm{E}_{\mathrm{m}}$ & 20 & $\begin{array}{l}\text { Hasim \& } \\
\text { Madhapi }\end{array}$ \\
$\begin{array}{l}\text { Koefisien } \\
\text { Gaya Angkat } \\
\begin{array}{l}\text { Koefisien } \\
\text { Gaya Hambat }\end{array}\end{array}$ & $C_{L}$ & 0,4 & $\begin{array}{l}\text { Hasim \& } \\
\text { Madhapi7) } \\
\text { Hasim \& } \\
\text { Madhapi }\end{array}$ \\
\hline
\end{tabular}

\section{Konsumsi Spesifik Bahan Bakar (Specific Fuel Consumption, $S F C_{P}$ )}

Konsumsi Spesifik Bahan Bakar, $S F C_{P}$, menyatakan massa bahan bakar yang digunakan dalam setiap satuan daya per satuan waktu. Untuk mendapatkan nilai ini maka perlu dilakukan tahapan perhitungan berikut ini:

- Menghitung luasan referensi sayap, ARef.

- Menghitung kecepatan jelajah (cruise speed), $V_{c}$.

- $\quad$ Menghitung Gaya Hambat (drag), D.

- Menghitung Daya Terbang yang dibutuhkan (Power Required), Pr.

Perhitungan luasan referensi sayap, $\mathrm{S}$. Dalam pengembangannya, PUNA BPPT telah mengalami modifikasi desain. Dari data dokumentasi teknis di tahun 20127), tercantum luas referensi sayap PUNA adalah 0,6 $\mathrm{m}^{2}$, dengan ukuran bentang sayap sepanjang $2.358 \mathrm{~mm}$. Pada pengembangan terbaru, desain PUNA BPPT diperbesar dimensi-dimensinya hingga bentang sayapnya mencapai $2.988,81 \mathrm{~mm}^{5)}$.

Maka, dengan menggunakan kuadrat perbandingan bentang sayap sebagai faktor skala perbesaran, luas referensi sayap pada prototipe saat ini dihitung sebagai berikut ${ }^{3)}$ :

$$
S=\left(\frac{b_{N}}{b_{\text {Pre }}}\right)^{2} \cdot A_{\text {Pre }}
$$

Dengan variabel:

$S \quad$ : Luas Referensi Sayap yang Baru (New Wing Reference Area)

$A_{\text {Pre }} \quad$ : Luas Referensi Sayap Purwarupa sebeluma (Previous Wing Reference Area), yaitu 0,6 $\mathrm{m}^{2}$.

$b_{N} \quad$ : Panjang bentang sayap pada Purwarupa yang baru (New Span), yaitu $2.988,81 \mathrm{~mm}$.

$b_{\text {Pre }}$ : Panjang bentang sayap pada Purwarupa sebelumnya (Previous Length of Span), yaitu $2.358 \mathrm{~mm}$.

Sehingga diperoleh nilai S seluas $0,9641 \mathrm{~m}^{2}$.

Perhitungan kecepatan jelajah, Vc. Ketika Pesawat Udara terbang menjelajah (Cruise Flight), maka terjadi kesetimbangan gayagaya yang diilustrasikan pada Gambar 10 .

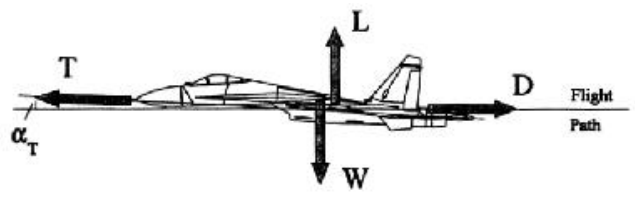

Gambar 10

Kesetimbangan Gaya Pada Pesawat Udara Sumber: Asselin ${ }^{3)}$

Dari diagram Kesetimbangan Gaya pada Pesawat Udara (diilustrasikan pada Gambar 10) ketika terbang dalam keadaan mantap (steady state), berlaku ${ }^{3)}$ :

$$
\begin{aligned}
& T-D=0 \\
& L-W=0
\end{aligned}
$$

Dengan notasi:

$T$ : Gaya Dorong (Thrust)

$D$ : Gaya Hambat (Drag)

$L$ : Gaya Angkat (Lift)

$W$ : Berat Pesawat (Weight)

Bila Persamaan (9) dimodifikasi menjadi:

$$
L=W
$$


Kemampuan Srategis Pesawat Udara NIR Awak BPPT untuk Dioperasikan dari Kapal Perang. (Jemie Muliadi, Dewi H. B., Akhmad Rifai, Dyah Jatiningrum)

Kemudian disubstitusikan ke persamaan (4) menjadi:

$$
W=\frac{1}{2} \rho V^{2} S C_{L}
$$

Maka kecepatan jelajah, $V_{c}$, dapat dihitung dari persamaan (11) yang bentuknya dimodifikasi sebagai berikut:

$$
V_{c}=\sqrt{\frac{M T O W \cdot g}{1 / 2 \cdot \rho \cdot S \cdot C_{L}}}
$$

Substitusi nilai-nilai berikut:

- MTOW, massa PUNA saat diluncurkan sebesar, $10,5 \mathrm{~kg}$

- $\quad g$, percepatan gravitasi sebesar 9,81 $\mathrm{m} / \mathrm{s}^{2}$.

- $\quad \rho$, massa jenis udara di permukaan laut sebesar $1,225 \mathrm{~kg} / \mathrm{m}^{3}$.

- $\quad S$, luas sayap, sebesar 0,9641 $\mathrm{m}^{2}$.

- $C_{L}$, koefisien gaya angkat pada kondisi Efisiensi Aerodinamika maksimum sebesar 0,4.

Ke persamaan (12) akan menghasilkan kecepatan jelajah, $V_{c}$, sebesar 40 knots atau $20,577 \mathrm{~m} / \mathrm{s}$.

Perhitungan gaya hambat, D, dapat dilakukan dengan persamaan (5).

$$
D=\frac{1}{2} \rho V^{2} S C_{D}
$$

Substitusi nilai-nilai berikut:

- $\quad g$, percepatan gravitasi sebesar 9,81 $\mathrm{m} / \mathrm{s}^{2}$.

- $\quad \rho$, massa jenis udara di permukaan laut sebesar $1,225 \mathrm{~kg} / \mathrm{m}^{3}$.

- V, kecepatan terbang PUNA sama dengan $\mathrm{V}_{\mathrm{C}}$, sebesar, $20,577 \mathrm{~m} / \mathrm{s}$

- $\quad S$, luas sayap, sebesar $0,9641 \mathrm{~m}^{2}$.

- $C_{D}$, koefisien gaya hambat pada kondisi Efisiensi Aerodinamika maksimum sebesar 0,02.

Menghasilkan gaya hambat, D, sebesar $5 \mathrm{~N}$.

Perhitungan kebutuhan Daya Terbang, $P_{r}$, dilakukan pada kondisi jelajah. Dengan memodifikasi persamaan (8) menjadi

$$
T=D
$$

Maka persamaan kebutuhan daya dari semula,

$$
P_{r}=T \cdot V_{c}
$$

$$
P_{r}=D \cdot V_{c}
$$

Maka, dengan gaya hambat (D) sebesar $5 \mathrm{~N}$, dan kecepatan jelajah ( $\mathrm{V}_{\mathrm{C}}$ ) sebesar 20,577 m/s, diperoleh Kebutuhan Daya Terbang, Pr, sebesar 102,889 Watt.

Perhitungan konsumsi spesifik bahan bakar, $\quad \mathrm{SFC}_{\mathrm{p}}, \quad$ dilakukan dengan menggunakan informasi Fuel Volume Rate ${ }^{5)}$, dan perhitungan kebutuhan daya terbang di atas. Dengan persamaan pembagian berikut ${ }^{3)}$ :

$$
S F C_{P}=\frac{\text { Fuel Volume Rate } \times \rho_{\text {Fuel }}}{P_{r}}
$$

Maka diperoleh nilai $S F C_{P}$ sebesar 9,759787 x $10^{-06} \mathrm{~kg} /$ Watt.s.

\section{Efisiensi Baling-Baling (Propeller Efficiency, $\eta_{p}$ )}

Efisiensi Baling-Baling adalah sebuah besaran yang menunjukkan perbandingan daya mesin (power) yang dapat diubah menjadi gaya dorong (thrust) ${ }^{8}$. Nilai parameter ini tergantung dari harga frekuensi putaran baling-baling (RPM atau $\mathrm{n}$ ), diameter baling-baling (d), sudut pitch baling-baling $(\varphi)$, dan massa jenis udara $(\rho)$. Tahapan untuk menghitung nilai efisiensi ini meliputi:

- Menghitung frekuensi putaran balingbaling ketika PUNA terbang jelajah, RPM.

- Menghitung Koefisien Gaya Dorong (Thrust) Tak-Berdimensi, $C_{T}$.

- Menghitung Koefisien Daya (Power) Tak-Berdimensi, $C_{P}$.

- Menghitung Rasio Advans (Advance Ratio), J.

Perhitungan frekuensi putaran balingbaling, RPM. G. Staples ${ }^{9}$, mempublikasikan regresi empirik yang dilakukannya terhadap 149 data pengukuran thrust. Staples melakukan regresi mulai dari baling-baling $5 " \times 5$ " hingga baling-baling $17 " \times 8$ ", baik pada kondisi statik dan juga kondisi dinamik. Regresi tersebut diterapkan untuk memodelkan hubungan empirik antara diameter, sudut pitch, RPM dan thrust yang dihasilkan baling-baling tersebut.

Dalam bentuk yang disederhanakannya, hasil regresi Staples dinyatakan dalam pemodelan berikut ${ }^{9)}$ : 


$$
\begin{aligned}
T= & 4.392399 \times 10^{-8} * R P M * \frac{d^{3.5}}{\sqrt{\varphi}} \\
& *\left\{\left(4.23333 \times 10^{-4} * R P M * \varphi\right)-V\right\}
\end{aligned}
$$

Dengan notasi:

$T \quad$ : Thrust (Gaya Dorong) yang dihasilkan, dalam satuan Newton.

$R P M \quad$ : Putaran Baling-Baling Per Menit

$d$ : Diameter Baling-Baling dalam satuan inci.

$\varphi \quad$ : Sudut Pitch Baling-baling dalam satuan inci.

$V \quad$ : Kecepatan Arah Depan ketika Baling-Baling bergerak maju dalam satuan $\mathrm{m} / \mathrm{s}$.

Substitusi nilai-nilai berikut:

- T, sama dengan Gaya Hambat saat PUNA terbang jelajah sebesar $5 \mathrm{~N}$.

- $d$, diameter baling-baling sebesar 14 inci.

- $\varphi$, sudut pitch baling-baling sebesar 6 inci.

- $V$, sama dengan kecepatan jelajah, sebesar $20,577 \mathrm{~m} / \mathrm{s}$.

Ke persamaan (17) akan menghasilkan persamaan kuadrat dengan RPM sebagai variabelnya. Dari 2 solusi yang diperoleh, maka dipilih harga RPM sebesar 6442 .

Perhitungan koefisien Gaya Dorong Tak Berdimensi, $C_{T}$, dilakukan sesuai definisi parameter tersebut menurut McCormick ${ }^{10)}$, yaitu:

$$
C_{T}=\frac{T}{\rho \cdot n^{2} \cdot d^{4}}
$$

Dengan notasi:

$T$ : Thrust (Gaya Dorong) dalam kondisi jelajah, sebesar $5 \mathrm{~N}$.

$n$ : Putaran Baling-Baling Per Detik, maka 6.442 RPM sama dengan 108,88 putaran per detik

d : Diameter Balling-Baling dalam meter, maka 14 inci sama dengan $0,3556 \mathrm{~m}$.

Sehingga diperoleh harga Koefisien Gaya Dorong (Thrust) Tak-Berdimensi, $\quad C_{T}$ sebesar $2,7503 \times 10^{-03}$.

Perhitungan koefisien Daya Tak Berdimensi, $C_{P}$, dilakukan sesuai definisi parameter tersebut ${ }^{11)}$, yaitu:

$$
C_{P}=\frac{P_{r}}{\rho \cdot n^{3} \cdot d^{5}}
$$

Dengan $P_{r}$ adalah Required Power (Kebutuhan Daya) dalam kondisi jelajah, sebesar 102,889 Watt. Sehingga diperoleh harga Koefisien Daya (Power) TakBerdimensi, $C_{P}$ sebesar 1,1618 $\times 10^{-02}$.

Perhitungan Rasio Advans, $J$, dilakukan sesuai definisi parameter tersebut ${ }^{11)}$, yaitu:

$$
J=\frac{V}{n \cdot d}
$$

Dengan $V$, Kecepatan jelajah, sebesar $20,577 \mathrm{~m} / \mathrm{s}$. Sehingga diperoleh harga Rasio Advans, $J$ sebesar 0,5342.

Penentuan efisiensi baling-baling, $\eta_{P}$, dilakukan dengan menggunakan kurva-kurva yang mengeplot nilai-nilai efisiensi balingbaling, $\eta_{p}$, sebagai fungsi Rasio Advans, $J$. Grafik tersebut diperoleh dari'2), sebagai berikut :

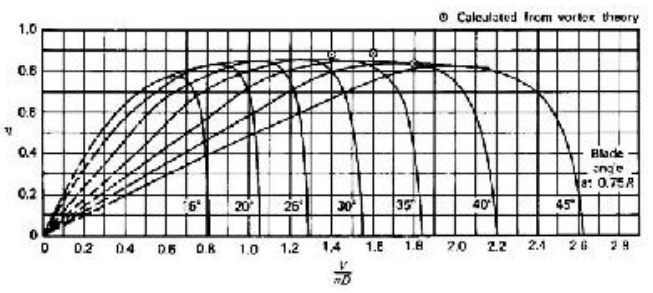

Gambar 11

Plot Efisiensi Baling-Baling terhadap Rasio Advans pada Berbagai Sudut P itch (Sumber: Bondline ${ }^{12}$ )

Untuk menggunakan plot pada Gambar 11 maka perlu dihitung sudut pitch balingbaling dari 6 inci menjadi besaran dalam satuan derajat. Dalam satuan inci, sudut pitch menyatakan pergeseran maju aliran udara pada $3 / 4$ panjang bilah dari pusat, ketika baling-baling berputar satu kali. Kondisi ini dimodelkan dengan relasi trigonometri ${ }^{12)}$ :

$$
\begin{aligned}
\tan \{\varphi(\text { degree })\} & =\frac{\varphi(\text { inch })}{\frac{3}{4} \cdot(\pi \cdot d)} \\
& =\frac{6}{\frac{3}{4} \cdot(\pi \cdot 14)}
\end{aligned}
$$

Sehingga diperoleh konversi sudut pitch, $\varphi$, menjadi 10 derajat.

Karena sudut pitch $10^{\circ}$ tidak terdapat dalam plot pada Gambar 11, maka, nilai efisiensi baling-baling $\eta_{p}$ akan diekstrapolasi 
Kemampuan Srategis Pesawat Udara NIR Awak BPPT untuk Dioperasikan dari Kapal Perang. (Jemie Muliadi, Dewi H. B., Akhmad Rifai, Dyah Jatiningrum)

dari kurva untuk sudut pitch $15^{\circ}$ dan kurva untuk sudut pitch $20^{\circ}$. Ekstrapolasi dilaksanakan menurut hubungan berikut ini:

$$
\begin{aligned}
& \eta_{P}\left(10^{\circ}\right)=\eta_{P}\left(15^{\circ}\right) \\
& +\frac{10^{\circ}-15^{\circ}}{20^{\circ}-15^{\circ}} \cdot\left\{\eta_{P}\left(20^{\circ}\right)-\eta_{P}\left(15^{\circ}\right)\right\}
\end{aligned}
$$

Dengan metoda grafis, maka dari plot efisiensi baling-baling, $\eta_{P}$, untuk Rasio Advans, $\mathrm{J}=0,5$ di Gambar 11, didapatkan harga $\eta_{P}\left(15^{\circ}\right)=0,74$ dan harga $\eta_{P}\left(20^{\circ}\right)=0,68$. Substitusi harga-harga tersebut ke persamaan (22) akan menghasilkan nilai efisiensi baling-baling, $\eta_{p}$, sebesar 0,80.

\section{Perhitungan J angkauan Terbang Maksimum}

Substitusi nilai-nilai dari parameter $S_{F} C_{P}$, $E_{m}, \eta_{p}$, dan $\zeta$ ke persamaan (1) menghasilkan jangkauan terbang sejauh $178,7 \mathrm{~km}$ atau 96,5 nautical mile. Jarak maksimum sebesar $178 \mathrm{~km}$ ini menggambarkan kemampuan PUNA untuk menjangkau suatu lokasi berjarak kira-kira $85 \mathrm{~km}$ atau 45 nautical mile dari lokasi take-off-nya, lalu melakukan pengambilan gambar atau misi lainnya, kemudian terbang kembali untuk mendarat.

\section{KETAHANAN TERBANG PUNA BPPT}

\section{Persamaan Ketahanan Terbang Maksimum}

Ketahanan Terbang (Endurance) adalah lamanya waktu penerbangan sebuah pesawat udara dengan sejumlah bahan bakar yang dibawa dalam sehimpunan kondisi terbang tertentu menurut Asselin ${ }^{3)}$.

Asselin, merumuskan persamaan Ketahanan Terbang Pesawat Udara dalam ekspresi berikut3):

$$
t_{\mathrm{Max}}=\frac{\eta_{P} E_{\mathrm{MP}}}{S F C_{P} V_{\mathrm{MP}}} \ln \left(\frac{1}{1-\varsigma}\right)
$$

Dengan notasi:

$t_{\text {Max }} \quad$ : Ketahanan Terbang Maksimum

$E_{M P}$ : Rasio perbandingan $C_{L}$ dan $C_{D}$ ketika $C_{L} \wedge 3 / C_{D} \wedge 2$ mencapai nilai maksimum.

\section{Aproksimasi Praktis Perhitungan Ketahanan Terbang Maksimum \\ Untuk memanfaatkan Perhitungan Jangkauan Maksimum (Range), maka}

Asselin melakukan aproksimasi sebagai berikut ${ }^{3)}$ :

$$
\frac{t_{\mathrm{max}}}{t_{X_{\mathrm{BR}}}}=\frac{E_{\mathrm{MP}}}{E_{\mathrm{BR}}}=\frac{1}{\sqrt{\frac{3}{4}}} \approx 1.155
$$

Dengan notasi:

$$
\begin{aligned}
t_{\mathrm{XBR}}: & \text { Lama Terbang untuk kondisi } \\
& \text { Jangkauan Terbang Maksimum } \\
E_{B R}: & \text { sama dengan } E_{M} \text {, nilai maksimum } \\
& \text { perbandingan } C_{L} \text { dan } C_{D} .
\end{aligned}
$$

Maka ketahanan terbang diaproksimasi dengan hubungan ${ }^{3)}$ :

$$
t_{\mathrm{max}} \approx 1.155 \times t_{X_{\mathrm{BR}}}
$$

Sehingga dapat dijabarkan menjadi3):

$$
t_{\mathrm{max}} \approx 1.155 \times \frac{\eta_{P} E_{\mathrm{BR}}}{S F C_{P} V_{\mathrm{BR}}} \ln \left(\frac{1}{1-\varsigma}\right)_{(26)}
$$

Dengan notasi:

$V_{B R}$ : sama dengan $V_{C}$, kecepatan jelajah PUNA BPPT untuk mencapai maximum range.

Substitusi nilai-nilai berikut:

- $\eta_{P}$, Koefisien efisiensi baling-baling sebesar, 0,8.

- $\quad E_{B R}$, sama dengan $E_{M}$, sebesar 20.

- $\quad S F C_{P}$, Konsumsi Bahan Bakar Tiap Satuan Waktu sebesar 9,759787 x 10-06 kg/Watt.s.

- $\quad V_{\mathrm{BR}}$, sama dengan $V_{C}$, sebesar 20,577 $\mathrm{m} / \mathrm{s}$.

- $\quad \zeta$ Rasio berat bahan bakar sebesar 0,1033 .

Ke persamaan (26) akan menghasilkan ketahanan terbang maksimum PUNA selama 2 jam 45 menit atau 2,75 jam.

\section{KETINGGIAN TERBANG PUNA BPPT}

\section{Ketinggian Terbang Maksimum}

Untuk memberi gambaran tentang ketinggian terbang maksimum PUNA BPPT, maka akan dihitung parameter service ceiling. Service ceiling adalah sebuah ukuran praktikal tentang batas atas ketinggian terbang yang menggambarkan kemampuan menanjak PUNA BPPT. Service ceiling didefinisikan sebagai ketinggian terbang ketika nilai Rate of Climb (Laju Pendakian 
Terbang) berkurang menjadi $0,5 \mathrm{~m} / \mathrm{s}$ atau $100 \mathrm{feet} /$ minute $^{11)}$.

Harga service ceiling PUNA diperoleh dengan plot Rate of Climb pada beberapa ketinggian terbang, kemudian dilakukan ekstrapolasi untuk mendapatkan ketinggian terbang pada kondisi Rate of Climb bernilai $100 \mathrm{feet} / \mathrm{minute}^{11)}$. Dengan demikian perlu dilakukan beberapa perhitungan berikut ini terlebih dahulu:

- Menghitung Rate of Climb (RC) pada ketinggian terbang (Altitude) $0 \mathrm{ft}, 1.000 \mathrm{ft}$ dan $2.000 \mathrm{ft}$ dari permukaan laut.

- Melakukan regresi linear pada plot RC vs Altitude.

- Menghitung ketinggian terbang ketika R ate of Climb bernilai 100 feet/minute.

\section{Perhitungan Maximum Rate of Climb}

Ruijgrok ${ }^{11)}$ menghitung Rate of Climb dari excess power (kelebihan daya) yang dialami Pesawat Udara :

$$
R C=\frac{P_{a}-P_{\mathrm{r}}}{W}
$$

Dengan notasi:

$$
\begin{aligned}
R C \quad: \text { Laju Pendakian Terbang (Rate of } \\
\\
\text { Climb). } \\
P_{a} \quad \begin{array}{l}
\text { : Daya Mesin Tersedia (Available } \\
\text { Power). }
\end{array}
\end{aligned}
$$

Sehingga persamaan Maximum Rate of Climb menjadi:

$$
R C_{\mathrm{Max}}=\frac{P_{a A l t}}{W}-\sqrt{\frac{W}{S} \cdot \frac{2}{\rho_{\mathrm{Alt}}} \cdot \frac{1}{\left(\frac{C_{L}^{3}}{C_{D}^{2}}\right)_{\text {Max }}}}
$$

Dengan notasi:

$$
\begin{aligned}
R C_{\text {Max }}: \text { Maximum Rate of Climb). } \\
P_{a A l t}: \text { Daya Mesin Tersedia (Available } \\
\\
\rho_{\text {Alt }} \quad \begin{array}{l}
\text { P ower) pada ketinggian lokal. } \\
\text { keting jaian yang dihitung. }
\end{array}
\end{aligned}
$$

Seiring dengan bertambahnya ketinggian terbang maka daya mesin lokal, $P_{a A l t}$, dan masa jenis udara lokal, $\rho_{\text {Alt }}$, akan mengalami penurunan sehingga nilai Maximum Rate of Climb akan ikut menurun. Maka, dalam langkah-langkah berikut akan disajikan perhitungan daya mesin lokal, $P_{a A l t}$, masa jenis udara lokal, $\rho_{A l t}$, serta nilai maksimum besaran tak berdimensi $\frac{C_{L}{ }^{3}}{C_{D}{ }^{2}}$.
Perhitungan daya mesin terhadap perubahan ketinggian, $P_{a} . \quad$ Rogers ${ }^{13)}$, mengaproksimasi pengaruh perubahan ketinggian terhadap daya mesin tersedia (Power Availlable) dengan asumsi hubungan linear sebagai berikut:

$$
P_{a A l t}=\delta \cdot P_{a S L}
$$

Dengan notasi:

$$
\begin{array}{ll}
\delta & : \text { Perbandingan tekanan udara di } \\
& \text { ketinggian lokal dengan tekanan } \\
& \text { udara di permukaan laut. } \\
P_{a S L} & : \begin{array}{l}
\text { Daya Mesin Tersedia (Available } \\
\text { Power) terukur di ketinggian } \\
\text { permukaan laut. }
\end{array}
\end{array}
$$

Nilai $\delta$ dapat diperoleh dari Tabel International Standard Atmosphere (ISA) dari Cavcar ${ }^{14)}$. Sedangkan $P_{a S L}$ disamakan dengan Daya Maksimum Mesin di permukaan laut sebesar 1.250 Watt.

Perhitungan massa jenis udara lokal terhadap perubahan ketinggian, $\rho_{\text {Alt }}$. Massa jenis udara dapat diukur dari persamaan gas ideal:

$$
\rho_{A l t}=\frac{p_{A l t}}{\Re \cdot T_{A l t}}
$$

Dengan notasi:

$$
\begin{array}{cl}
p_{\text {Alt }} & : \text { Tekanan udara lokal. } \\
\mathfrak{R} & : \text { Konstanta gas. } \\
T_{\text {Alt }} & : \text { Temperatur Absolut Lokal. }
\end{array}
$$

Untuk aplikasi praktis, massa jenis udara lokal dapat dihitung dari density ratio:

$$
\rho_{\text {Alt }}=\sigma \cdot \rho
$$

Dengan notasi density ratio, $\sigma$, menyatakan perbandingan massa jenis udara di ketinggian lokal terhadap massa jenis udara di permukaan laut. Nilai density ratio, $\sigma$, dapat diperoleh dari Ruijgrok ${ }^{11)}$.

Perhitungan nilai maksimum besaran tak berdimensi, $\frac{C_{L}{ }^{3}}{C_{D}{ }^{2}}$. Dari persamaan (28) terlihat bahwa upaya memaksimumkan nilai $R C_{\text {Max }}$ dilakukan dengan meminimumkan suku di dalam tanda akar pada ruas kanan. Minimalisasi suku tersebut terwujud bila besaran $\frac{C_{L}{ }^{3}}{C_{D}{ }^{2}}$ yang menjadi penyebut pecahan, dibuat menjadi maksimal.

Dari kurva koefisien gaya angkat PUNA BPPT, $C_{L}$, dan koefisien gaya hambatnya, $C_{D}$, 
Kemampuan Srategis Pesawat Udara NIR Awak BPPT untuk Dioperasikan dari Kapal Perang. (Jemie Muliadi, Dewi H. B., Akhmad Rifai, Dyah Jatiningrum)

(Hasim \& Madhapi ${ }^{7)}$ ) dapat dihitung $\frac{C_{L}{ }^{3}}{C_{D}{ }^{2}}$ yang ditampilkan pada grafik di Gambar 12:

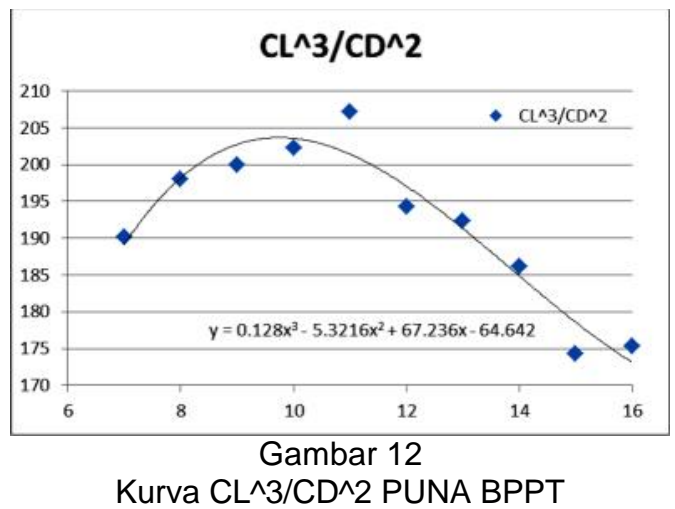

Sehingga nilai maksimal $\frac{C_{L}{ }^{3}}{C_{D}{ }^{2}}$ dapat diperoleh dari regresi pada scatter di Gambar 12 yaitu sebesar 202.

\section{Harga Service Ceiling}

Nilai Service Ceiling akan ditentukan dengan terlebih dahulu menghitung Maximum Rate of Climb pada beberapa titik. Setelah diperoleh plot titik-titik tersebut, lalu dilakukan regresi untuk menentukan ketinggian dengan Rate of Climb maksimum sebesar $100 \mathrm{ft} / \mathrm{min}$.

Tabel 3.

Input Perhitungan Maximum Rate of C $\lim b$

\begin{tabular}{lcccc}
\multicolumn{1}{c}{ Altitude } & $\boldsymbol{\delta}$ & PaAlt & $\boldsymbol{\sigma}$ & pAlt \\
\hline Sea Level & 1 & 1250 & 1 & 1.225 \\
$1000 \mathrm{ft}$ & 0.9644 & 1205.5 & 0.9711 & 1.189 \\
$2000 \mathrm{ft}$ & 0.9298 & 1162.3 & 0.9428 & 1.154 \\
\hline
\end{tabular}

Untuk mendapatkan Maximum Rate of Climb pada Sea Level, ketinggian $1000 \mathrm{ft}$ dan $2000 \mathrm{ft}$, maka besaran pada Tabel 3 disubtitusikan ke persamaan (28). Hasil-hasil Maximum Rate of Climb tersebut ditampilkan dalam scatter pada Gambar 13 .

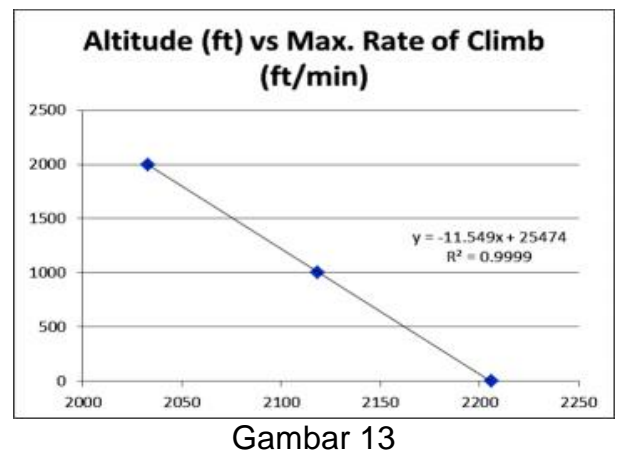

Grafik Maximum Rate of Climb PUNA BPPT

Selanjutnya, scatter pada Gambar 13 diregresi sehingga diperoleh persamaan yang menghubungkan ketinggian dengan Maximum Rate of Climb sebagai berikut:

$$
h=-11.549 \cdot R C_{\text {Max }}+25474
$$

Dengan notasi $h$, menyatakan ketinggian terbang PUNA dari permukaan laut. Maka, substitusi $R C_{\text {Max }}$ sebesar $100 \mathrm{ft} / \mathrm{min}$ menghasilkan ketinggian terbang sebesar $24.319 \mathrm{ft}$. Oleh karena itu diperoleh kesimpulan sementara bahwa ketinggian Service Ceiling PUNA BPPT adalah $24.000 \mathrm{ft}$. Dengan kata lain, PUNA BPPT mampu terbang hingga ketinggian $24.000 \mathrm{ft}$ akibat daya maksimum mesinnya.

Tabel 4.

Waktu Mendaki dengan Maximum Rate of Climb

\begin{tabular}{rcccc}
\hline $\begin{array}{c}\text { Ketinggian } \\
\text { terbang }\end{array}$ & $\begin{array}{c}\text { RoC Max } \\
(\mathrm{m} / \mathrm{s})\end{array}$ & Jam & Menit & Detik \\
\hline $5.000 \mathrm{ft}$ & 9.09 & 0 & 7 & 36 \\
$9.000 \mathrm{ft}$ & 7.60 & 0 & 25 & 39 \\
$10.000 \mathrm{ft}$ & 7.26 & 0 & 32 & 19 \\
$15.000 \mathrm{ft}$ & 5.67 & 1 & 22 & 53 \\
$19.000 \mathrm{ft}$ & 4.56 & 2 & 31 & 08 \\
$20.000 \mathrm{ft}$ & 4.30 & 2 & 53 & 24 \\
$24.000 \mathrm{ft}$ & 3.33 & 4 & 50 & 37 \\
\hline
\end{tabular}

Walaupun performa pendakian PUNA BPPT mencapai ketinggian terbang hingga $24.000 \mathrm{ft}$, namun dari hasil perhitungan pada Tabel 4, ketinggian ini mampu dicapai dalam 4 jam 50 menit. Sedangkan hasil perhitungan ketahanan terbang PUNA di persamaan (26) menunjukkan ketahanan terbang maksimum PUNA adalah 2 jam 45 menit atau 2,75 jam. Dengan demikian, sekalipun PUNA BPPT diterbangkan mendaki selama 2 jam 45 menit tersebut, maka ketinggian terbang yang dapat dicapai hanyalah sebatas $19.000 \mathrm{ft}$.

Dengan batasan ketahanan terbang selama 2 jam 45 menit, dan lamanya misi setidaknya 30 menit, dan 30 menit tambahan adalah waktu jelajah PUNA dari kapal menuju lokasi misinya, maka sangat logis untuk menganggap bahwa waktu menanjak yang paling mungkin adalah separuh dari 1 jam, yaitu selama 30 menit. Dari Tabel 4, PUNA BPPT mencapai ketinggian terbang $9.000 \mathrm{ft}$ dalam 25 menit, dan ketinggian $10.000 \mathrm{ft}$ dicapai dalam 32 menit. Dengan demikian, diasumsikan ketinggian terbang maksimum PUNA BPPT akan dibatasi oleh bahan bakar yang dibawanya, yaitu setinggi $10.000 \mathrm{ft}$.

\section{DISKUSI}

Keunggulan penggunaan PUNA dalam misi patroli perbatasan, adalah kemampuan operasionalnya dalam misi-misi 3D yaitu dull, 
dirty, dan dangerous menurut Stenger et $\mathrm{al}^{15)}$. Dull adalah sifat misi yang berlangsung lama dan juga terus-menerus, contohnya misi pengawasan. Dirty adalah sifat misi yang berlangsung pada daerah yang tercemar, seperti misalnya pada daerah paparan radiasi akibat penggunaan senjata nuklir atau kimia. Dangerous adalah sifat misi yang berlangsung pada daerah yang berbahaya bagi keselamatan awak, seperti pengintaian di garis depan peperangan.

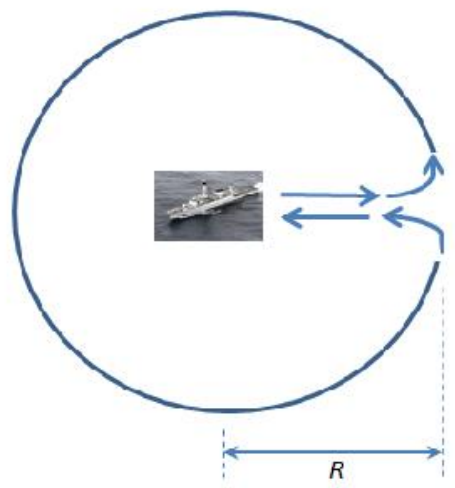

Gambar 14

Sketsa Lintasan PUNA BPPT dalam Monitoring Sekeliling Kapal Perang

Operasi PUNA di atas kapal perang dapat mendukung pelaksanaan misi rutin dan misi khusus kapal perang tersebut. Misi rutin di sini adalah berupa patroli perbatasan dan patroli garis pantai di samping berbagai misi strategis PUNA seperti yang diuraikan oleh Austin ${ }^{18)}$. Untuk memberi gambaran kemampuan PUNA dalam mendukung misi kapal perang, maka diilustrasikan sebuah misi monitoring di sekeliling kapal seperti pada Gambar 14. Dalam misi monitoring ini, PUNA terbang sejauh Radius area monitoring, $\mathrm{R}$, untuk kemudian memutari area tersebut, lalu kembali ke titik asalnya. Maka jarak yang ditempuh, $\mathrm{X}$, adalah:

$$
X=2 R+2 \pi R=2 R(1+\pi)
$$

Dengan nilai $X$ sebesar Jarak Jangkau Maksimum $178 \mathrm{~km}$, maka diperoleh monitoring area radius, $\mathrm{R}$, sejauh $21 \mathrm{~km}$ atau 11 nautical mile.

Oleh karena itu, PUNA BPPT dapat melakukan terbang jelajah hingga ketinggian $10.000 \mathrm{ft}$ untuk mengawasi daerah di dalam radius $21 \mathrm{~km}$ dari titik peluncuran. Pengawasan dilakukan dengan payload yang dipasang pada PUNA BPPT, antara lain dapat berupa kamera beresolusi tinggi, ataupun night vision camera. Hasil penginderaan ini dikirimkan ke Ground Control Station (GCS) untuk ditampilkan dan ditafsirkan. Setelah melakukan tugasnya, PUNA BPPT terbang kembali ke kapal, kemudian mendarat pada jaring pendarat yang telah disiapkan.

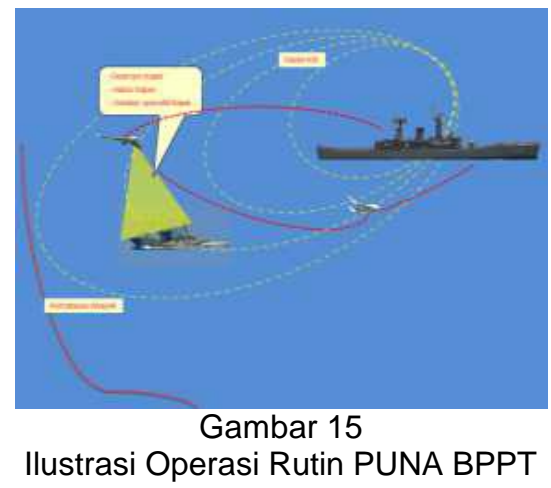

Untuk misi khusus, PUNA dapat melakukan pengintaian, pengumpulan informasi baru, dan juga dilibatkan dalam operasi gabungan. Dalam melakukan misi pengintaian, PUNA diterbangkan ke arah kapal musuh atau pulau yang akan diintai. Sebagai contoh, bila terjadi perompakan dan penyanderaan, maka payload PUNA akan mengirimkan informasi grafis dari obyek yang diintainya. Kemudian di GCS, citra grafis ini akan ditafsirkan untuk menentukan jumlah penyandera, persenjataannya dan keadaan sandera. Sehingga hasil penafsiran ini akan menjadi informasi yang mendukung operasi pembebasan.

Pelaksanaan misi khusus semacam ini membutuhkan PUNA yang mampu terbang dalam durasi terbang yang cukup lama untuk melakukan pengumpulan informasi. Dari kemampuan PUNA BPPT untuk terbang selama 2,75 jam, sudah memadai dalam misi reconnaissance.

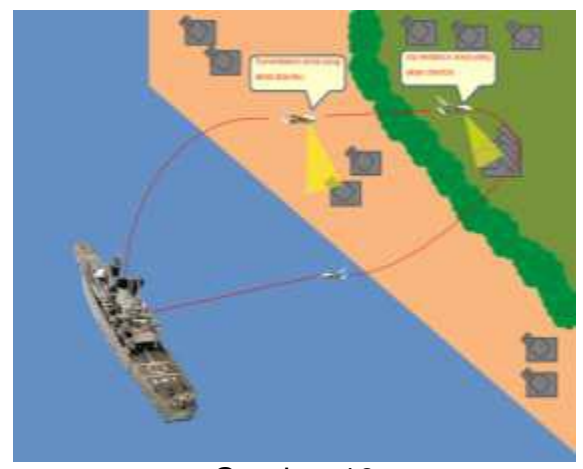

Gambar 16

Ilustrasi Operasi Khusus PUNA

Dalam melakukan misi pengumpulan informasi baru PUNA dioperasikan sebagai "mata" bagi kapal perang. Dengan payload berupa kamera, maka PUNA diterbangkan 
Kemampuan Srategis Pesawat Udara NIR Awak BPPT untuk Dioperasikan dari Kapal Perang. (Jemie Muliadi, Dewi H. B., Akhmad Rifai, Dyah Jatiningrum)

hingga melewati horison. Dari informasi grafis yang dikirimkan, maka kapal perang dapat mengetahui kondisi kapal yang berada di dekatnya dengan lebih akurat.

Bila PUNA diterbangkan ke suatu titik yang telah ditetapkan, lalu kembali pulang, maka titik terjauh yang dapat dijangkau adalah $89 \mathrm{~km}$ dari posisi awal, atau 48 nautical mile. Sehingga PUNA dapat diterapkan untuk mendukung operasi gabungan, terutama dalam melakukan verifikasi dari obyek yang diindera oleh radar.

\section{SIMPULAN}

Pesawat PUNA BPPT dapat dengan mudah dioperasikan dari atas kapal perang RI khususnya kapal perang berkelas fregat karena PUNA BPPT mempunyai kemampuan dapat melakukan monitoring mission hingga radius $21 \mathrm{~km}$ dari kapal perang, PUNA BPPT juga dapat menjangkau titik terjauh hingga jarak $89 \mathrm{~km}$ dari kapal perang tempat ia diluncurkan, PUNA BPPT mampu terbang hingga ketinggian maksimum operasional setinggi $10.000 \mathrm{ft}$.

Maka pesawat PUNA BPPT dapat digunakan untuk membantu misi rutin dan misi khusus kapal perang $\mathrm{TNI} A \mathrm{~L}$, termasuk mengawasi pulau-pulau terluar Indonesia. Hal ini akan memupuk kepedulian seluruh komponen bangsa terhadap pulau-pulau keci yang menjadi batas terluar wilayah $\mathrm{NKRI}^{20}$ ).

\section{SARAN}

Penelitian ini dapat diteruskan dengan menambahkan pengaruh cuaca dalam simulasi pengoperasian PUNA BPPT. Dengan bervariasinya kecepatan angin, serta arahnya, dan juga gelombang, maka faktor cuaca perlu diperhitungkan dalam analisa lanjutan.

\section{UCAPAN TERIMA KASIH}

Ucapan terima kasih disampaikan kepada Dislitbang TNI-AL atas dukungannya dalam penulisan makalah ini.

\section{DAFTAR PUSTAKA}

1. Pregiwati, L. A., P otensi Sektor Kelautan Indonesia Menjanjikan, Siaran Pers KKP, http://kkp.go.id/index.php/ pers/potensi-sektor-kelautanindonesiamenjanjikan/, Jakarta, 2015
2. Kementerian Pertahanan Republik Indonesia, Buku Putih Pertahanan Indonesia 2015, Kementerian Pertahanan Republik Indonesia, Jakarta, https://www.kemhan.go.id/wpcontent/uploads/2016/04/BPPI-INDO2015.pdf, 2015

3. Asselin, M., An Introduction to Aircraft Performance, AIAA Education Series, AIAA Inc., Vancouver USA, 1997.

4. Budiarti, D.H., Djatmiko dan Dahsyat, M., Technical Report No. 012/FT/6.1/ PUNA/XI/2013, Laporan Pengujian PUNA BPPT-04C Sriti Eksperimental Flight No. 02 Test Subject: "Parameter Identification", Tertanggal 01 November, Dok. Intern. PTIPK-BPPT, Jakarta, 2013.

5. Budiarti, D.H., Djatmiko dan Dahsyat, M., Technical Report No. 001/FT/6.1/ PUNA/IV/2013, Laporan Pengujian PUNA BPPT-04C Sriti Eksperimental Flight No. 04-05 Test Subject: "New Engine Assessment", Tertanggal 25-26 April, Dok. Intern. PTIPK-BPPT, Jakarta, 2013.

6. Sururi, E dan Waluyo, B., Kaji Eksperimen: Perbandingan Penggunaan Bahan Bakar Premium dan Pertamax terhadap Unjuk Kerja Mesin pada Sepeda Motor Suzuki Thunder Tipe EN125, http://oto.teknik.ummgl.ac.id/wpcontent/uploads/2013/06/KAJI-

Eksperimen-Perbandingan-

Penggunaan-Bahan-Bakar-PremiumDan-Pertamax-Terhadap-Unjuk-KerjaMesin.pdf, diakses 2015.

7. Hasim, F., dan Madhapi, Program Document No. 021.2.F1.133, Laporan Akhir Kegiatan Program Riset Insentif PKPP .Pengembangan Konfigurasi Aerodinamika Pesawat udara Nir-Awak (PUNA-BPPT) Prototipe Sriti untuk Peningkatan Jarak Jelajah dan Daya Tahan Terbang, Dok. Intern. LAGGBPPT, Banten, 2012.

8. http://www.epi-eng.com/propeller technology/ selecting_a_propeller.htm, Propeller Performance Factors: Basic Information to Help Selecting the Correct Propeller, diakses Agustus 2015.

9. Staples, G., Propeller Static \& Dynamic Thrust Calculation, http:// electricaircraftguy.blogspot.com/2013/ 09/propeller-static-dynamic-thrustequation.html, diakses Agustus 2015.

10. McCormick, B. W., Aerodynamics, Aeronautics and Flight Mechanics, JohnWiley and Sons, New York, 1979. 
11. Ruijgrok, G. J. J., Elements of Airplane Performance, Delft University Press, Delft, The Netherlands, 1994.

12. http://bondline.org/wiki/

Basic_Engine_and_Propeller Performance, 2008, diakses Agustus 2015.

13. Rogers, D. F., Altitude Effects (Part 1), http://www.nar-associates.com/ technical-flying/altitude/part1/ altitude_part1_wide_screen.pdf, diakses Agustus 2015.

14. Cavcar, M., The International Standard Atmosphere (ISA), http://home.anadolu. edu.tr/ mcavcar/ISAweb.pdf, diakses Agustus 2015.

15. Stenger, A., Fernando, B., \& Heni, M., 2012, Autonomous Mission Planning for UAVs: A Cognitive Approach, SILVER ATENA Electronic Systems Engineering $\mathrm{GmbH}$, Munich, Germany.

16. US National Research Council, Autonomous Vehcles in Support of Naval Operations, US National Academy of Sciences, 2005. Washington D.C., USA.
17. Jane, F. T. \& Sharpe, Capt. R. OBE RN (editor). 1997. Jane's Fighting Ships 1997-98, 100 th ed., Thomson Publishing.

18. Austin, R. Unmanned Aircraft Systems: UAVs Design, Development and Deployment, John Wiley \& Sons, London, UK, 2010

19. http://id.wikipedia.org/wiki/KRI_Ahmad_ Yani_(351), diakses Oktober 2017

20. Sondakh, B.K., Peran TNI AL dalam Pengamanan dan Pemberdayaan Pulau Terluar RI, Jurnal Hukum dan Pembangunan, Vol.33, No.1, 2003.

21. Franklin, J. A., Dynamics, Control, and Flying Qualities of V/STOL Aircraft, AIAA Inc., Reston Virginia, USA, 2002.

22. DSF World Bank. Rencana Strategis Pulau Sulawesi: Pembangunan Kapasitas untuk Perumusan Kebijakan Pembangunan Daerah (Tahap II), Decentralization Support Facility, Jakarta, Indonesia, 2011. 